\title{
Correction to: Spatial patterns of yield-based cropping suitability and its driving factors in the three main maize-growing regions in China
}

\author{
Jin Zhao ${ }^{1} \cdot$ Xiaoguang Yang ${ }^{1}$
}

Published online: 30 December 2019

(C) ISB 2019

\section{Correction to: International Journal of Biometeorology (2019) 63: 1659-1668} https://doi.org/10.1007/s00484-019-01783-1

Due to an author oversight, the original article was published with erroneous funding information in the acknowledgement section. The author group and publisher apologize for the error as the information should be recognized as it is appears below and not the former:

This work was supported by the National Key Research and Development Program of China (2017YFD0300301) and the Donation for China Clean Development Mechanism Fund (2014109).

This correction stands to correct the original article. The original article has been corrected.

Publisher's note Springer Nature remains neutral with regard to jurisdictional claims in published maps and institutional affiliations.

The online version of the original article can be found at https:/doi.org/ 10.1007/s00484-019-01783-1

Xiaoguang Yang

yangxg@cau.edu.cn

1 College of Resources and Environmental Sciences, China

Agricultural University, Beijing, 100193 China 